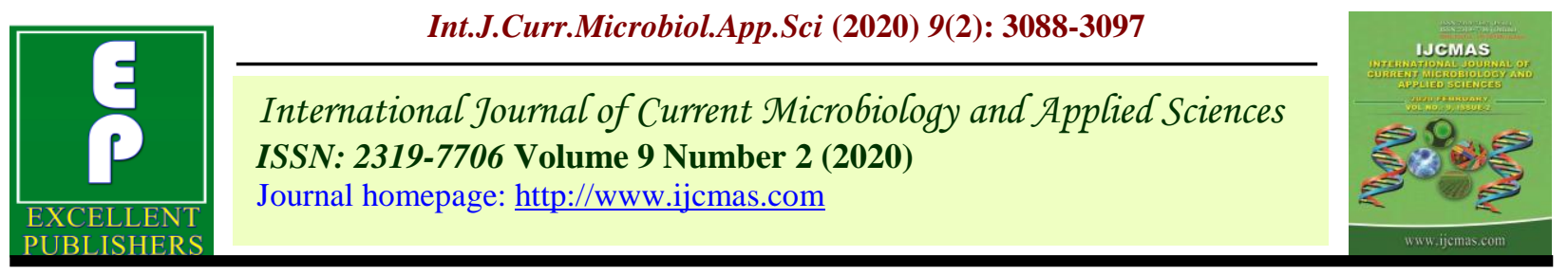

Original Research Article

https://doi.org/10.20546/ijcmas.2020.902.356

\title{
Growth, Yield and Economics of Pigeonpea as Influenced by Biofortification of Zinc and Iron
}

\author{
Saakshi, R. Almad, Pandit S. Rathod*, V. Rachappa, B. M. Dodamani and N. Ananda
}

Department of Agronomy, Zonal Agricultural Research Station, Aland Road, Kalaburagi - 585 101, Karnataka, India

*Corresponding author

Keywords

$\mathrm{ZnSO}_{4}, \mathrm{FeSO}_{4}, \mathrm{Zn}$ EDTA, Fe EDTA, plant height, leaf area, grain yield, stalk yield

Article Info

Accepted:

26 January 2019

Available Online:

10 February 2020

A B S T R A C T

A field experiment was conducted to study "Growth, yield and economics of pigeonpea as influenced by biofortification of zinc and iron" during kharif 2017 at Agriculture Research Station, Kalaburgi on black clay soil. The experiment was laid out in randomized complete block design with ten treatments and three replications comprising of both soil and foliar application of zinc and iron. Among the treatments, RDF + soil application of $\mathrm{ZnSO}_{4} @ 15 \mathrm{~kg} \mathrm{ha}^{-1}$ followed by foliar application $0.5 \% \mathrm{Zn}$ EDTA recorded significantly higher growth attributes viz. plant height $(252.5 \mathrm{~cm})$, number of primary branches $(23.42)$, secondary branches (25.42), leaf area (17.08), leaf area index (0.95), total dry matter accumulation (210.79 g) at harvest and yield attributes viz. number of pods per plant (169.67), seed yield per plant $(51.41 \mathrm{~g})$, pod yield per plant $(86.27 \mathrm{~g})$ and 100 seed weight $(12.05 \mathrm{~g})$, as compared to rest of the treatments. Among the different biofortification treatments, significantly higher grain yield $\left(1897 \mathrm{~kg} \mathrm{ha}^{-1}\right)$, stalk yield (4760 kg ha $\left.{ }^{-1}\right)$, husk yield $\left(1654 \mathrm{~kg} \mathrm{ha}^{-1}\right)$, net returns (Rs. $\left.86933 \mathrm{ha}^{-1}\right)$ and B: $\mathrm{C}$ ratio (3.89) was obtained in $\mathrm{RDF}+$ soil application of $\mathrm{ZnSO}_{4} @ 15 \mathrm{~kg} \mathrm{ha}^{-1}$ followed by foliar application of $0.5 \% \mathrm{Zn}$ EDTA. Significantly lower growth, yield attributes and economics were recorded with recommended dose of NPK only.

\section{Introduction}

Pulses occupy an area of 76 million hectares and contribute 69 million tonnes to world's food basket (Anon., 2015a). India has the distinction of being world's largest producer of pulses; with the production of 23.95 million tonnes annually from an area of 28.83 million hectares with average productivity of $831 \mathrm{~kg} \mathrm{ha}^{-1}$ (Anon., 2017). India contributes $25 \%$ to the global pulse production from 32 $\%$ area. Pigeonpea is one of the protein rich legumes of the semi-arid tropics grown predominantly under rainfed conditions. In Karnataka, pigeonpea occupies an area of 8.85 lakh hectares, producing 7.29 lakh 
tonnes with an average productivity of $824 \mathrm{~kg}$ $\mathrm{ha}^{-1}$ (Anon., 2017). Pigeonpea is grown in almost all the states and larger portion of the area lies in the states like Maharashtra, Uttar Pradesh, Madhya Pradesh, Karnataka and Gujarat.

The productivity of pigeonpea in Karnataka is very low as compared to national level (831 $\left.\mathrm{kg} \mathrm{ha}^{-1}\right)$. The low productivity of pigeonpea is mainly attributed to their cultivation in poor soils with inadequate and imbalanced nutrient application without the application of micronutrients (Mukundagowda et al., 2014).

Biofortification is the process of creating micronutrient denser staple food crops with increased bioavailable concentrations through agronomic intervention or genetic selection.

Biofortification works for twin objective of increasing the concentration of the micronutrients in the grains and simultaneously improving the bioavailability of micronutrients in the grains to alleviate the micronutrient deficiency in human beings and also animals.

Hence agronomic biofortification of zinc and iron can be done through soil and foliar applications. The use of micronutrient in pigeonpea is one of the ways to boost up the productivity and to improve the seed quality parameters (Arjun Sharma et al., 2009).

Hence, the present investigation was undertaken to study the effect of soil and foliar application and zinc and iron on growth and yield of pigeonpea.

\section{Materials and Methods}

A field experiment was conducted during the kharif 2017 at Agriculture Research Station, Kalaburgi, is situated at North Eastern Dry Zone of Karnataka at a latitude of $17^{\circ} 34^{\prime}$
North, longitude of $76^{\circ} 79^{\prime}$ East and an altitude of 478 meters above mean sea level. The experiment was laid out in Randomized complete block design with 10 treatments replicated thrice.

The treatments were, $\mathrm{T}_{1}$ : Recommended dose of NPK (control), $\mathrm{T}_{2}$ : RDF $+2 \%$ urea foliar application at flowering, $\mathrm{T}_{3}: \mathrm{RDF}+0.5 \% \mathrm{Zn}$ EDTA foliar application at flowering, $\mathrm{T}_{4}$ : $\mathrm{RDF}+0.1 \% \mathrm{Fe}$ EDTA foliar application at flowering, $\mathrm{T}_{5}$ : RDF+ Zn EDTA (0.5\%) and Fe EDTA $(0.1 \%)$ through foliar application at flowering, $\mathrm{T}_{6}$ : RDF+ Soil application of $\mathrm{ZnSO}_{4} @ 15 \mathrm{~kg} \mathrm{ha}^{-1}, \mathrm{~T}_{7}: \mathrm{RDF}+$ Soil application of $\mathrm{FeSO}_{4} @ 15 \mathrm{~kg} \mathrm{ha}^{-1}$, T8: RDF+ Soil application of $\mathrm{ZnSO}_{4} @ 15 \mathrm{~kg} \mathrm{ha}^{-1} \mathrm{fb}$ foliar application of $0.5 \% \mathrm{Zn}$ EDTA , $\mathrm{T}_{9}$ : $\mathrm{RDF}+$ Soil application of $\mathrm{FeSO}_{4} @ 15 \mathrm{~kg} \mathrm{ha}^{-1}$ $f b$ foliar application of $0.1 \%$ Fe EDTA, $\mathrm{T}_{10}$ : $\mathrm{RDF}+$ Soil application of $\mathrm{ZnSO}_{4} @ 15 \mathrm{~kg} \mathrm{ha}$ ${ }^{1}+\mathrm{FeSO}_{4} @ 15 \mathrm{~kg} \mathrm{ha}^{-1}$.

Recommended dose of fertilizer for pigeonpea (25:50:0 kg N: $\mathrm{P}_{2} \mathrm{O}_{5}: \mathrm{K}_{2} \mathrm{O}$ ) were applied at the time of sowing. Nitrogen, phosphorous and potassium were applied in the form of diammonium phosphate (DAP) and Farm yard manure (FYM) @ $6 \mathrm{t} \mathrm{ha}^{-1}$ was incorporated into soil two weeks before sowing. The sowing was done on $18^{\text {th }}$ july, 2017. The total rainfall received during the cropping season $667.70 \mathrm{~mm}$.

The soil of the experimental site was black clay, slightly alkaline (8.30) with an electrical conductivity of $0.2 \mathrm{dS} \mathrm{m}$. The soil organic carbon content was low $(0.49 \%)$.

The soil was low in available nitrogen (232 $\mathrm{kg} \mathrm{ha}^{-1}$ ), medium in available phosphorus (29 $\mathrm{kg} \mathrm{ha}^{-1}$ ) and high in available potassium (430 $\mathrm{kg} \mathrm{ha}^{-1}$ ) and available zinc and Iron (1.76 ppm and $9.72 \mathrm{ppm})$ respectively. Soil application of fertilizers at 30 DAS and foliar application of fertilizers at $50 \%$ flowering stage. 


\section{Results and Discussion}

\section{Effect of soil and foliar application of zinc and iron on growth parameters}

The plant height of pigeonpea differed significantly due to soil and foliar application of micronutrients. In the present study, significantly higher plant height $(252.5 \mathrm{~cm})$ recorded with $\mathrm{RDF}+$ soil application of $\mathrm{ZnSO}_{4} @ 15 \mathrm{~kg} \mathrm{ha}^{-1} \mathrm{fb}$ foliar application of $0.5 \% \mathrm{Zn}$ EDTA $\left(\mathrm{T}_{8}\right)$ over other treatments ( Table 1.) may be due to application of micronutrients with RDF responded better in terms of growth and yield attributes due to balanced availability of micronutrients and moisture throughout growing period and application of zinc increased activity of meristematic cells and cell elongation, favorable effect on metabolic process (Price et al., 1972).

Similar kind of results were also found by Sharma et al., (2010) opined that application of $\mathrm{ZnSO}_{4} @ 15 \mathrm{~kg} \mathrm{ha}^{-1}+\mathrm{RDF}$ recorded significantly higher plant height $(196.1 \mathrm{~cm})$ compared to the application of RDF alone in pigeonpea, Der et al., (2015) reported that combined application K @ 0.5\% + Fe @ $0.5 \%+Z n @ 0.5 \%+\mathrm{B} @ 0.2 \%$ foliar spray at 40 DAS results in significantly higher plant height, over the control in groundnut, Gowthami and Ananda (2015) reported that micronutrient application soil $\left(25 \mathrm{~kg} \mathrm{ha}^{-1}\right)$ and foliar $(0.5 \%)$ application of $\mathrm{ZnSO}_{4}$ recorded significantly higher plant height $(42.09 \mathrm{~cm})$ in groundnut, Jha et al., (2015) reported that application of $100 \% \mathrm{RDF}+\mathrm{Zn}+\mathrm{Fe}(\mathrm{N}: \mathrm{P}: \mathrm{K}-$ 20:30:15 $\mathrm{kg} \mathrm{ha}^{-1}+\mathrm{ZnSO}_{4} 5 \mathrm{~kg} \mathrm{ha}^{-1}+\mathrm{FeSO}_{4}$ $5 \mathrm{~kg} \mathrm{ha}^{-1}$ ) recorded significantly highest plant height $(34.18 \mathrm{~cm})$ of blackgram respectively over rest of the treatments. Among the treatments tested, significantly higher number of branches was recorded with $\mathrm{RDF}+$ soil application of $\mathrm{ZnSO}_{4} @ 15 \mathrm{~kg} \mathrm{ha}^{-1} \mathrm{fb}$ foliar application of $0.5 \% \mathrm{Zn}$ EDTA $\left(\mathrm{T}_{8}\right)$ over other treatments (Table 1). This might be due to superiority of $\mathrm{ZnSO} 4$ in maintaining higher zinc concentration in the rhizosphere and beneficial role of zinc in synthesis of IAA, metabolism of auxin, biological activity, stimulating effect on photosynthetic pigments and enzyme activity which inturn encourage vegetative growth of plants.

Application of $\mathrm{ZnSO}_{4} @ 15 \mathrm{~kg} \mathrm{ha}^{-1}+\mathrm{RDF}$ recorded significantly higher number of primary branches per plant (10.1) compared to the application of RDF alone in pigeonpea (Sharma et al., 2010). Application of $\mathrm{FeSO}_{4}$ $+\mathrm{ZnSO}_{4} @ 25 \mathrm{~kg} \mathrm{ha}^{-1}+$ borax @ $5 \mathrm{~kg} \mathrm{ha}^{-1}$ along with recommended dose of fertilizer recorded the higher number of branches at all growth stages followed by $\mathrm{FeSO}_{4}+\mathrm{ZnSO}_{4}$ each@10 kg ha ${ }^{-1}+$ borax @ $2.5 \mathrm{~kg} \mathrm{ha}^{-1}$ along with RDF in chickpea (Mahantesh, 2013). Der et al., (2015) reported that combined application K@0.5\% + Fe @ $0.5 \%+\mathrm{Zn} @ 0.5 \%+\mathrm{B} @ 0.2 \%$ foliar spray at 40 DAS results in significantly higher number of branches per plant over the control. Roy et al., (2017) reported that soil application of $\mathrm{Zn}$ at $5.5 \mathrm{~kg} \mathrm{ha}^{-1}$ increases the number of branches per plant over control in greengram.

Leaf area is an important attribute of plant which determines the active photosynthetic ability, growth, dry matter production and inurn yield of any crop. Leaf area index which depends on leaf area per plant can be widely changed by manipulating cultural practices. Significantly higher leaf area index recorded with RDF + soil application of $\mathrm{ZnSO}_{4} @ 15$ $\mathrm{kg} \mathrm{ha}^{-1} \mathrm{fb}$ foliar application of $0.5 \% \mathrm{Zn}$ EDTA $\left(\mathrm{T}_{8}\right)$ over other treatments (Table 1).

Due to increased metabolic activity by increased supply of nutrients, more accumulation of dry matter in leaves helped the photosynthetic area to remain active for longer period and was responsible for overall 
growth of plant interms of dry matter production. Almost similar results were found by Gowthami and Ananda (2015) reported that micronutrient application soil $\left(25 \mathrm{~kg} \mathrm{ha}^{-1}\right)$ and foliar $(0.5 \%)$ application of $\mathrm{ZnSO}_{4}$ recorded significantly higher leaf area at harvest (6.30 $\mathrm{dm}^{2}$ plant $^{-1}$, respectively) and Handiganoor et al., (2016) reported that seed polymer coating $\left(6 \mathrm{ml} \mathrm{kg} \mathrm{kg}^{-1}\right)$ of pigeonpea seeds with the combination of potassium molybdate $+\mathrm{ZnSO}_{4}+$ boron (each @ $2 \mathrm{~g} \mathrm{~kg}^{-1}$ seed) along with two foliar sprays of potassium molybdate $(0.1 \%)+$ zinc sulphate $(0.5 \%)$ in EDTA form + borax $(0.2 \%)$ at an interval of 10 days during flowering stage (75 and 85 DAS) recorded significantly higher leaf area index $(2.48,3.08$ and 2.91) at 45, 90 and 120 DAS respectively compared to control. Jha et al., (2015) reported that application of $100 \% \mathrm{RDF}+\mathrm{Zn}+\mathrm{Fe}(\mathrm{N}: \mathrm{P}: \mathrm{K}-$ 20:30:15 kg ha ${ }^{-1}+\mathrm{ZnSO}_{4} 5 \mathrm{~kg} \mathrm{ha}^{-1}+\mathrm{FeSO}_{4}$ $5 \mathrm{~kg} \mathrm{ha}^{-1}$ ) recorded significantly highest leaf area index (2.216) over rest of the treatments in blackgram, Mukundgouda et al., (2015) revealed that soil application of $\mathrm{ZnSO}_{4} @ 25$ $\mathrm{kg} \mathrm{ha}^{-1}$ along with foliar spray of 19:19:19 @ $0.4 \%$ recorded significantly higher leaf area per plant in pigeonpea.

In the present investigation, $\mathrm{RDF}+$ soil application of $\mathrm{ZnSO}_{4} @ 15 \mathrm{~kg} \mathrm{ha}^{-1} \mathrm{fb}$ foliar application of $0.5 \% \mathrm{Zn}$ EDTA $\left(\mathrm{T}_{8}\right)$ recorded significantly higher dry matter accumulation (210.79 g plant $^{-1}$ ) over other treatments (Table 1). This may be due to soil and foliar application of $\mathrm{ZnSO}_{4}$ along with RDF which ultimately increased nutrient concentration in root zone followed by spraying of fertilizers through leaves, increased nutrient availability and uptake, increased transplantation of photosynthates from source to sink, hence higher dry matter production.

The treatment receiving only recommended dose of NPK (control) recorded significantly lowest dry matter accumulation (154.68 g plant $^{-1}$ ) due to poor availablity of nutrients, lower nutrient uptake compared to application of micronutrient application along with RDF. Similar results were also found with application of $\mathrm{FeSO}_{4}+\mathrm{ZnSO}_{4} @ 25 \mathrm{~kg} \mathrm{ha}^{-1}$ + borax@ $5 \mathrm{~kg} \mathrm{ha}^{-1}$ along with recommended dose of fertilizer recorded higher dry matter production at all growth stages followed by $\mathrm{FeSO}_{4}+\mathrm{ZnSO}_{4}$ each@10 kg ha ${ }^{-1}+$ borax @ $2.5 \mathrm{~kg} \mathrm{ha}^{-1}$ along with RDF in chickpea (Mahantesh, 2013). Der et al., (2015) reported that combined application K @ 0.5\% +Fe@0.5\%+Zn@0.5\%+B@0.2\% foliar spray at 40 DAS results in significantly higher dry matter at 45 and 75 DAS over the control in groundnut. Application of $100 \%$ $\mathrm{RDF}+\mathrm{Zn}+\mathrm{Fe}\left(\mathrm{N}: \mathrm{P}: \mathrm{K}-20: 30: 15 \mathrm{~kg} \mathrm{ha}^{-1}+\right.$ $\left.\mathrm{ZnSO}_{4} 5 \mathrm{~kg} \mathrm{ha}^{-1}+\mathrm{FeSO}_{4} 5 \mathrm{~kg} \mathrm{ha}^{-1}\right)$ recorded significantly highest dry matter $\left(10.31 \mathrm{~g}\right.$ plant $^{-}$ ${ }^{1}$ ) of blackgram respectively over rest of the treatments (Jha et al., 2015). Krishna and P. J. George (2017) reported that soil application of phosphorus @70 kg ha ${ }^{-1}$ and $\mathrm{ZnSO}_{4} @ 20$ $\mathrm{kg} \mathrm{ha}{ }^{-1}$ recorded significantly higher dry weight $(35 \mathrm{~g})$ in kabuli chickpea.

\section{Effect of soil and foliar application of zinc and iron on yield parameters}

In the present investigation, significant differences were noticed in yield and yield components of pigeonpea as a consequence of biofortification of micronutrients involving different methods of application. All the biofortified treatments produced significantly higher seed yield (1475-1897 $\left.\mathrm{kg} \mathrm{ha}^{-1}\right)$ when compared to control (1329 kg ha-1) (Table 2). Control treatment registered $42.7 \%$ reduction in seed yield as compared to the best treatment RDF + soil application of $\mathrm{ZnSO}_{4} @ 15 \mathrm{~kg} \mathrm{ha}^{-1} \mathrm{fb}$ foliar application of $0.5 \% \mathrm{Zn}$ EDTA $\left(\mathrm{T}_{8}\right)$. Higher grain yield obtained in this treatment may be due to higher dry matter accumulation, better nutrient uptake (N, P, K, Zn and $\mathrm{Fe}$ ) and translocation to reproductive parts and 
involvement of zinc in various enzymatic processes which helps in catalyzing reaction for growth finally leading to development of more yield attributing characters like number of pods per plant, pod weight, 100 seed weight, and seed yield. Significantly lower seed yield $\left(1329 \mathrm{~kg} \mathrm{ha}^{-1}\right)$ obtained with recommended dose of NPK $\left(T_{1}\right)$ may be due to lower availability of major and micronutrient in soil, lower nutrient uptake, reduced photosynthates production which causes lower yield attributing characters and resulted in lower yield.

The improvement in yield was mainly achieved through improvement in yield attributing characters like number of pods plant $^{-1}$, pod yield plant ${ }^{-1}$, seed yield plant ${ }^{-1}$ and 100 seed weight (Table 2). In this study, significantly higher number of pods per plant (169.67), pod weight $\left(86.27 \mathrm{~g} \mathrm{plant}^{-1}\right), 100$ seed weight $(12.05 \mathrm{~g})$ and seed yield $(51.41 \mathrm{~g}$ plant $^{-1}$ ) was recorded with $\mathrm{RDF}+$ soil application of $\mathrm{ZnSO}_{4} @ 15 \mathrm{~kg} \mathrm{ha}^{-1} \mathrm{fb}$ foliar application of $0.5 \% \mathrm{Zn}$ EDTA $\left(\mathrm{T}_{8}\right)$ when compared to rest of the treatments (Table 2).

Higher seed yield plant ${ }^{-1}$ may be due to fulfillment of the demand of crop by higher assimilation and translocation of photosynthates from source to sink and better role of zinc during reproductive phase of crop growth. Seed yield plant ${ }^{-1}$ was governed by number of pods plant ${ }^{-1}$, number of seeds pod ${ }^{-1}$ and 100 seed weight.

Significantly higher number of pods plant ${ }^{-1}$ was recorded with RDF + soil application of $\mathrm{ZnSO}_{4} @ 15 \mathrm{~kg} \mathrm{ha}^{-1} \mathrm{fb}$ foliar application of $0.5 \%$ Zn EDTA $\left(\mathrm{T}_{8}\right)$ over control. Gowthami and Ananda (2015) reported that micronutrient application soil $\left(25 \mathrm{~kg} \mathrm{ha}^{-1}\right)$ and foliar $(0.5 \%)$ application of $\mathrm{ZnSO}_{4}$ recorded significantly higher plant height and leaf area at harvest $\left(42.09 \mathrm{~cm}\right.$ and $6.30 \mathrm{dm}^{2}$ plant $^{-1}$, respectively) and pod yield $\left(2656 \mathrm{~kg} \mathrm{ha}^{-1}\right)$.
Srikanth Babu et al., (2012) reported that significantly higher seed yield of pigeonpea $\left(1324 \mathrm{~kg} \mathrm{ha}^{-1}\right)$ can be obtained with $\mathrm{ZnSO}_{4} @$ $20 \mathrm{~kg} \mathrm{ha}^{-1}$ compared to no zinc sulphate ( $\left.1048 \mathrm{~kg} \mathrm{ha}^{-1}\right)$ and $\mathrm{ZnSO}_{4} @ 10 \mathrm{~kg} \mathrm{ha}^{-1}(1,171$ $\mathrm{kg} \mathrm{ha}^{-1}$ ) while it was on par with $\mathrm{ZnSO}_{4} @ 15$ $\mathrm{kg} \mathrm{ha}^{-1}\left(1296 \mathrm{~kg} \mathrm{ha}^{-1}\right)$.

Debroy et al., (2013) revealed that both soil and foliar application of $5.5 \mathrm{~kg} \mathrm{Zn} \mathrm{ha}{ }^{-1}+$ $0.1 \% \mathrm{Zn}$ spray through $\mathrm{ZnSO}_{4}$ resulted in increase in straw yield by $56.4 \%$ and seed yield by $57 \%$ in greengram. Gowthami and Ananda (2015) reported that micronutrient application soil $\left(25 \mathrm{~kg} \mathrm{ha}^{-1}\right)$ and foliar $(0.5 \%)$ application of $\mathrm{ZnSO}_{4}$ recorded significantly higher pod yield $\left(2656 \mathrm{~kg} \mathrm{ha}^{-1}\right)$ in groundnut and application of $100 \% \mathrm{RDF}+\mathrm{Zn}+\mathrm{Fe}$ (N:P:K- 20:30:15 kg ha ${ }^{-1}+\mathrm{ZnSO}_{4} 5 \mathrm{~kg} \mathrm{ha}^{-1}$ $+\mathrm{FeSO}_{4} 5 \mathrm{~kg} \mathrm{ha}^{-1}$ ) recorded significantly highest number of pods (32.38 plant $\left.^{-1}\right)$, number of seeds $\left(6.88 \mathrm{pod}^{-1}\right)$, seed yield $(870$ $\left.\mathrm{kg} \mathrm{ha}^{-1}\right)$, straw yield $\left(1843 \mathrm{~kg} \mathrm{ha}^{-1}\right)$, biological yield $\left(2713 \mathrm{~kg} \mathrm{ha}^{-1}\right)$ of blackgram respectively over rest of the treatments (Jha et al., 2015).

The data on stalk yield and husk yield of pigeonpea due to biofortification of $\mathrm{Zn}$ and $\mathrm{Fe}$ indicated that, significantly higher stalk yield $\left(4761 \mathrm{~kg} \mathrm{ha}^{-1}\right)$ and husk yield (1655 $\left.\mathrm{kg} \mathrm{ha}^{-1}\right)$ were recorded with RDF + soil application of $\mathrm{ZnSO}_{4} @ 15 \mathrm{~kg} \mathrm{ha}^{-1} \mathrm{fb}$ foliar application of $0.5 \% \mathrm{Zn}$ EDTA $\left(\mathrm{T}_{8}\right)$ over other treatments.

The higher stalk yield and husk yield in the above said treatment may be due to improved vegetative growth and growth parameters through adequate availability of major and micronutrient in soil, which in turn, favorably influenced physiological process and buildup of photosynthates.

Almost similar results were found by Ramaprasad et al., (2011) revealed that soil application of $25 \mathrm{~kg} \mathrm{ZnSO}_{4} \mathrm{ha}^{-1}$ along with $0.5 \% \mathrm{ZnSO}_{4}$ foliar spray of twice at 45 and 55 
DAS proved significantly superior over the control in seed yield $\left(3046 \mathrm{~kg} \mathrm{ha}^{-1}\right)$ and haulm yield $\left(3891 \mathrm{~kg} \mathrm{ha}^{-1}\right)$ in kabuli chickpea under clay loam soils of Andhra Pradesh., Debroy et al., (2013) studied enrichment of green gram genotypes with iron through ferti-fortification and concluded that both soil and foliar application of $5.5 \mathrm{~kg} \mathrm{Zn} \mathrm{ha}^{-1}+0.1 \% \mathrm{Zn}$ spray through $\mathrm{ZnSO}_{4}$ resulted in increase in straw yield by $56.4 \%$ and seed yield by $57 \%$.

Table.1 Growth attributes of pigeonpea as influenced by soil and foliar application of $\mathrm{Zn}$ and $\mathrm{Fe}$

\begin{tabular}{|c|c|c|c|c|c|c|}
\hline Treatment & $\begin{array}{c}\text { Plant } \\
\text { height } \\
(\mathrm{cm})\end{array}$ & $\begin{array}{c}\text { No. of } 1^{\circ} \\
\text { branches }^{-1} \\
\text { plant }^{-1}\end{array}$ & $\begin{array}{c}\text { No. of } 2^{\circ} \\
\text { branches }^{-1} \\
\text { plant }^{-1}\end{array}$ & $\begin{array}{c}\text { Leaf area } \\
\left(\mathbf{d m}^{2}\right. \\
\left.\text { plant }^{-1}\right)\end{array}$ & $\begin{array}{c}\text { Leaf } \\
\text { area } \\
\text { index }\end{array}$ & $\begin{array}{c}\text { TDMA } \\
\text { (g) }\end{array}$ \\
\hline $\begin{array}{l}T_{1} \text { : Recommended dose of } \\
\text { NPK (control) }\end{array}$ & 185.7 & 14.07 & 18.93 & 10.37 & 0.58 & 154.68 \\
\hline $\begin{array}{l}\mathrm{T}_{2}: \mathrm{RDF}+2 \% \text { urea foliar } \\
\text { application }\end{array}$ & 201.9 & 14.95 & 19.37 & 12.17 & 0.67 & 174.69 \\
\hline $\begin{array}{l}\mathrm{T}_{3}: \mathrm{RDF}+0.5 \% \mathrm{Zn} \text { EDTA } \\
\text { foliar application }\end{array}$ & 229.7 & 17.14 & 21.93 & 13.19 & 0.73 & 191.62 \\
\hline $\begin{array}{l}\mathrm{T}_{4}: \mathrm{RDF}+0.1 \% \text { Fe EDTA } \\
\text { foliar application }\end{array}$ & 208.2 & 15.20 & 19.54 & 12.22 & 0.68 & 177.26 \\
\hline 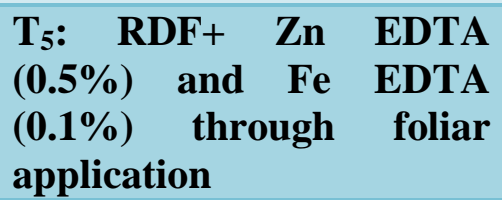 & 239.6 & 18.47 & 23.36 & 14.61 & 0.81 & 199.32 \\
\hline $\begin{array}{l}\mathrm{T}_{6}: \mathrm{RDF}+\text { Soil application } \\
\text { of } \mathrm{ZnSO}_{4} @ 15 \mathrm{~kg} \mathrm{ha}^{-1}\end{array}$ & 235.3 & 17.47 & 22.83 & 14.10 & 0.78 & 195.31 \\
\hline $\begin{array}{l}\mathrm{T}_{7}: \mathrm{RDF}+\text { Soil application } \\
\text { of } \mathrm{FeSO}_{4} @ 15 \mathrm{~kg} \mathrm{ha}^{-1}\end{array}$ & 214.1 & 15.47 & 19.93 & 12.47 & 0.69 & 180.90 \\
\hline $\begin{array}{l}\mathrm{T}_{8}: \mathrm{RDF}+\text { Soil application } \\
\text { of } \mathrm{ZnSO}_{4} @ 15 \mathrm{~kg} \mathrm{ha}^{-1} \mathrm{fb} \\
\text { foliar application of } 0.5 \% \\
\text { Zn EDTA }\end{array}$ & 252.5 & 23.42 & 25.42 & 17.08 & 0.95 & 210.79 \\
\hline $\begin{array}{l}\text { T}_{9}: \mathrm{RDF}+\text { Soil application } \\
\text { of } \mathrm{FeSO}_{4} @ 15 \mathrm{~kg} \mathrm{ha}^{-1} \mathrm{fb} \\
\text { foliar application of } 0.1 \% \\
\text { Fe EDTA }\end{array}$ & 224.9 & 16.47 & 20.53 & 12.98 & 0.72 & 184.87 \\
\hline $\begin{array}{l}\mathrm{T}_{10}: \quad \mathrm{RDF}+{ }^{+} \text {Soil } \\
\text { application of } \mathrm{ZnSO}_{4} @ 15 \\
\mathrm{~kg} \mathrm{ha}^{-1}+\mathrm{FeSO}_{4} @ 15 \mathrm{~kg} \\
\mathrm{ha}^{-1}\end{array}$ & 247.3 & 19.00 & 24.25 & 14.85 & 0.83 & 205.53 \\
\hline S.Em \pm & 9.9 & 1.72 & 1.50 & 1.22 & 0.067 & 3.91 \\
\hline $\mathrm{CD}(\mathrm{p}=\mathbf{0 . 0 5})$ & 29.4 & 5.52 & 4.82 & 3.91 & 0.22 & 12.51 \\
\hline CV (\%) & 7.66 & 17.41 & 12.08 & 15.79 & 15.74 & 3.61 \\
\hline
\end{tabular}


Table.2 Yield and yield attributes of pigeonpea as influenced by soil and foliar application of $\mathrm{Zn}$ and $\mathrm{Fe}$

\begin{tabular}{|c|c|c|c|c|c|c|c|}
\hline Treatments & $\begin{array}{l}\text { No. of } \\
\text { pods } \\
\text { plant }^{-1}\end{array}$ & $\begin{array}{l}\text { Pod weight } \\
\text { Plant }^{-1}(g)\end{array}$ & $\begin{array}{l}\text { Seed yield } \\
\text { Plant }^{-1}(g)\end{array}$ & $\begin{array}{c}\text { Test } \\
\text { weight } \\
\text { (g) }\end{array}$ & $\begin{array}{c}\text { Grain } \\
\text { yield } \\
\left(\mathrm{kg} \mathrm{ha}^{-1}\right)\end{array}$ & $\begin{array}{c}\text { Stalk } \\
\text { yield (kg } \\
\left.\text { ha }^{-1}\right)\end{array}$ & $\begin{array}{c}\text { Husk } \\
\text { yield (kg } \\
\left.\text { ha }^{-1}\right)\end{array}$ \\
\hline $\begin{array}{l}T_{1} \text { : Recommended dose of } \\
\text { NPK (control) }\end{array}$ & 105.67 & 45.13 & 32.55 & 9.79 & 1329 & 3088 & 1185 \\
\hline $\begin{array}{l}\mathrm{T}_{2}: \mathrm{RDF}+2 \% \text { urea foliar } \\
\text { application }\end{array}$ & 125.00 & 62.27 & 34.68 & 10.35 & 1475 & 3417 & 1310 \\
\hline $\begin{array}{l}\mathrm{T}_{3}: \mathrm{RDF}+0.5 \% \mathrm{Zn} \mathrm{EDTA} \\
\text { foliar application }\end{array}$ & 147.33 & 73.27 & 45.30 & 11.24 & 1639 & 3876 & 1451 \\
\hline $\begin{array}{l}\mathrm{T}_{4}: \mathrm{RDF}+0.1 \% \mathrm{Fe} \text { EDTA } \\
\text { foliar application }\end{array}$ & 132.33 & 65.33 & 35.28 & 10.73 & 1487 & 3461 & 1326 \\
\hline $\begin{array}{l}T_{5}: \text { RDF+ Zn EDTA }(0.5 \%) \\
\text { and Fe EDTA }(0.1 \%) \\
\text { through foliar application }\end{array}$ & 158.33 & 80.47 & 48.65 & 11.46 & 1656 & 3971 & 1483 \\
\hline $\begin{array}{l}\mathrm{T}_{6}: \mathrm{RDF}+\text { Soil application } \\
\text { of } \mathrm{ZnSO}_{4} @ 15 \mathrm{~kg} \mathrm{ha}^{-1}\end{array}$ & 151.33 & 77.93 & 47.13 & 11.37 & 1648 & 3914 & 1465 \\
\hline $\begin{array}{l}\mathrm{T}_{7}: \mathrm{RDF}+\text { Soil application } \\
\text { of } \mathrm{FeSO}_{4} @ 15 \mathrm{~kg} \mathrm{ha}^{-1}\end{array}$ & 136.67 & 67.00 & 36.47 & 10.74 & 1530 & 3550 & 1359 \\
\hline $\begin{array}{l}\text { T}_{8}: \mathrm{RDF}+\text { Soil application } \\
\text { of } \mathrm{ZnSO}_{4} @ 15 \mathrm{~kg} \mathrm{ha}^{-1} \mathrm{fb} \\
\text { foliar application of } 0.5 \% \\
\text { Zn EDTA }\end{array}$ & 169.67 & 86.27 & 51.41 & 12.05 & 1897 & 4761 & 1655 \\
\hline $\begin{array}{l}\mathrm{T}_{9}: \mathrm{RDF}+\text { Soil application } \\
\text { of } \mathrm{FeSO}_{4} @ 15 \mathrm{~kg} \mathrm{ha}^{-1} \mathrm{fb} \\
\text { foliar application of } 0.1 \% \\
\text { Fe EDTA }\end{array}$ & 140.33 & 68.33 & 38.10 & 10.98 & 1598 & 3708 & 1419 \\
\hline $\begin{array}{l}\mathrm{T}_{10}: \mathrm{RDF}+\text { Soil application } \\
\text { of } \mathrm{ZnSO}_{4} @ 15 \mathrm{~kg} \mathrm{ha}^{-1}+ \\
\mathrm{FeSO}_{4} @ 15 \mathrm{~kg} \mathrm{ha}^{-1}\end{array}$ & 164.33 & 83.18 & 49.59 & 11.56 & 1738 & 4337 & 1532 \\
\hline S.Em \pm & 7.77 & 5.23 & 2.22 & 0.408 & 87 & 216 & 67 \\
\hline $\mathrm{CD}(\mathrm{p}=0.05)$ & 24.88 & 16.75 & 7.11 & 1.307 & 261 & 690 & 215 \\
\hline
\end{tabular}


Table.3 Economic of pigeonpea as influenced by biofortification of zinc and iron

\begin{tabular}{|c|c|c|c|c|}
\hline Treatments & $\begin{array}{l}\text { Gross returns } \\
\quad\left(₹ \text { ha }^{-1}\right)\end{array}$ & $\begin{array}{l}\text { Cost of } \\
\text { cultivation } \\
\left(₹ h^{-1}\right)\end{array}$ & $\begin{array}{r}\text { Net returns } \\
\quad\left(₹ \text { ha }^{-1}\right)\end{array}$ & $\mathrm{BC}$ ratio \\
\hline $\begin{array}{l}T_{1}: \text { Recommended dose of NPK } \\
\text { (control) }\end{array}$ & 81,877 & 26,570 & 55,307 & 3.08 \\
\hline $\begin{array}{l}\mathrm{T}_{2}: \quad \mathrm{RDF}+2 \% \text { urea foliar } \\
\text { application }\end{array}$ & 90,863 & 26,838 & 59,918 & 3.23 \\
\hline $\begin{array}{l}\mathrm{T}_{3}: \mathrm{RDF}+0.5 \% \mathrm{Zn} \text { EDTA foliar } \\
\text { application }\end{array}$ & $1,01,003$ & 29,020 & 71,983 & 3.48 \\
\hline $\begin{array}{l}\mathrm{T}_{4}: \mathrm{RDF}+0.1 \% \text { Fe EDTA foliar } \\
\text { application }\end{array}$ & 91,613 & 27,470 & 64,144 & 3.34 \\
\hline $\begin{array}{l}\text { T}_{5}: \text { RDF+ Zn EDTA }(0.5 \%) \text { and Fe } \\
\text { EDTA }(0.1 \%) \text { through foliar } \\
\text { application }\end{array}$ & $1,02,087$ & 29,720 & 72,367 & 3.44 \\
\hline $\begin{array}{l}\mathrm{T}_{6}: \text { RDF+ Soil application of } \\
\mathrm{ZnSO}_{4} @ 15 \mathrm{~kg} \mathrm{ha}^{-1}\end{array}$ & $1,01,570$ & 27,395 & 74,175 & 3.71 \\
\hline $\begin{array}{l}\mathrm{T}_{7}: \mathrm{RDF}+\text { Soil application of } \\
\text { FeSO }_{4} @ 15 \mathrm{~kg} \mathrm{ha}^{-1}\end{array}$ & 94,254 & 27,020 & 67,234 & 3.49 \\
\hline $\begin{array}{l}\mathrm{T}_{8}: \mathrm{RDF}+\text { Soil application of } \\
\mathrm{ZnSO}_{4} @ 15 \mathrm{~kg} \mathrm{ha}^{-1} \mathrm{fb} \text { foliar } \\
\text { application of } 0.5 \% \mathrm{Zn}^{2} \text { EDTA }\end{array}$ & $1,17,028$ & 29,845 & 87,183 & 3.92 \\
\hline $\begin{array}{l}\text { T9: RDF+ Soil application of } \text { RD+ } \\
\text { FeSO }_{4} @ 15 \mathrm{~kg} \mathrm{ha}^{-1} \mathrm{fb} \text { foliar } \\
\text { application of } 0.1 \% \text { Fe EDTA }\end{array}$ & 98,444 & 27,920 & 70,524 & 3.53 \\
\hline $\begin{array}{l}\mathrm{T}_{10}: \mathrm{RDF}+\text { Soil application of } \\
\mathrm{ZnSO}_{4} @ 15 \mathrm{~kg} \mathrm{ha}^{-1}+\mathrm{FeSO}_{4} @ 15 \\
\mathrm{~kg} \mathrm{ha}^{-1}\end{array}$ & $1,07,214$ & 27,845 & 79,369 & 3.85 \\
\hline S.Em \pm & 4870 & - & 4870 & 0.10 \\
\hline $\mathrm{CD}(\mathrm{p}=\mathbf{0 . 0 5})$ & 15,578 & - & 15,578 & 0.31 \\
\hline
\end{tabular}

\section{Economics}

Among treatments, significantly higher gross return ( $₹ 1,17,028 \mathrm{ha}^{-1}$ ), net return ( $₹$ $87,183 \mathrm{ha}^{-1}$ ) and benefit cost ratio (3.92) were recorded with RDF + soil application of $\mathrm{ZnSO}_{4} @ 15 \mathrm{~kg} \mathrm{ha}^{-1} \mathrm{fb}$ foliar application of $0.5 \% \mathrm{Zn}$ EDTA when compared to rest of the treatments (Table 3). Significantly higher gross return, net return and $\mathrm{BC}$ ratio in the above treatment was due to higher yield levels and higher market price of pigeonpea. The higher yields under this treatment may be due to soil application of fertilizers which might be resulted in higher nutrient concentration in root zone and direct foliar spraying of 
fertilizers leads to more absorption of nutrients, better photosynthetic activity and its distribution to various parts, increase in growth and yield attributing characters and finally resulted in higher yields, gross returns, net return and benefit cost ratio. Almost similar result found in Mukundagowda et al., (2014) revealed that soil application of $\mathrm{ZnSO}_{4}$ @ $25 \mathrm{~kg} \mathrm{ha}^{-1}$ along with foliar spray of 19:19:19 @ 0.4 \% recorded significantly higher gross returns (₹ 55,592 $\mathrm{ha}^{-1}$ ), net returns ( $₹ 36,323 \mathrm{ha}^{-1}$ ) and benefit cost ratio (2.89). Jha et al., (2015) reported that application of $100 \% \mathrm{RDF}+\mathrm{Zn}+\mathrm{Fe}(\mathrm{N}: \mathrm{P}: \mathrm{K}-$ 20:30:15 kg ha ${ }^{-1}+\mathrm{ZnSO}_{4} 5 \mathrm{~kg} \mathrm{ha}^{-1}+\mathrm{FeSO}_{4} 5$ $\mathrm{kg} \mathrm{ha}^{-1}$ ) recorded significantly highest gross return ( $₹ 50975$ ha $^{-1}$ ), net return ( $₹ 34930$ ha ${ }^{1}$ ) and $\mathrm{B}: \mathrm{C}$ ratio (3.18) respectively over rest of the treatments in blackgram. Rathod et al., (2016) concluded that application of $\mathrm{ZnSO}_{4}$ @ $15 \mathrm{~kg} \mathrm{ha}^{-1}$ along with recommended dose of fertilizers recorded significantly higher gross returns (₹ 59,039 ha-1), net returns (₹ 38,209 $\mathrm{ha}^{-1}$ ) and B: C ratio (2.83).

Among the treatments, RDF + soil application of $\mathrm{ZnSO}_{4} @ 15 \mathrm{~kg} \mathrm{ha}^{-1} \mathrm{fb}$ foliar application of $0.5 \% \mathrm{Zn}$ EDTA $\left(\mathrm{T}_{8}\right)$ recorded significantly higher growth parameters like plant height, number of branches, leaf area, leaf area index, total dry matter accumulation and yield parameters like grain yield, stalk yield husk yield, number of pods per plant, seed yield per plant, pod yield per plant and 100 seed weight. Significantly higher net return and BC ratio recorded with treatment, $\mathrm{RDF}+$ soil application of $\mathrm{ZnSO}_{4} @ 15 \mathrm{~kg} \mathrm{ha}^{-1} \mathrm{fb}$ foliar application of $0.5 \% \mathrm{Zn}$ EDTA $\left(\mathrm{T}_{8}\right)$.

\section{References}

Anonymous, 2015a, Annual Report, Department of Agriculture, Cooperation and Farmers Welfare, Ministry of Agriculture and Farmers Welfare, Government of India, Krishi Bhavan,
New Delhi.

Anonymous, 2017, Project Co-ordinators Report, All India Co-ordinated Research Project on Pigeonpea, ICAR - Indian Institute of Pulses Research Kanpur; 2017-18.

Arjun Sharma, Arjun Sharma, Anil Kumar and Potdar, M.P., 2009, Response of pigeonpea to conjunctive use of organic and inorganic source of fertilizers under rainfed conditions. Karnataka J. Agric. Sci., 22: 8-10.

Debroy, P., Narwal, R. P., Malik, R. S. and Narendar, 2013, Impact of zinc application method on green gram (Vigna radiata) productivity and grain zinc fortification. J. Environ. Biol., 35: 851-54.

Der, H. N., Vaghasia, P.M., and Verma, H. P., 2015, Effect of foliar application of potash and micronutrients on growth and yield attributes of groundnut. Ann. Agric. Res. New series, 36(3): 275-278.

Gowthami, S.S., and Ananda, N., 2015, Effect of zinc and iron ferti-fortification on growth, pod yield and zinc uptake of groundnut (Arachis hypogaea L.) genotypes. Int. J. Agric., Environ. and Biotech., 10(5): 575-580.

Handiganoor, M. G., Patil, S. B. and Vasudevan, S. N., 2016, Response of pigeonpea (Cajanus cajan L.) to seed polymerization with micronutrients and foliar spray at different growth stages. British J. Environ. and Climate Change 7(4): 205-213.

Jha, D. P., Sharma, S. K. and Amarawat, T., 2015, Effect of organic and inorganic sources of nutrients on yield and economics of blackgram (Vigna mungo L.) grown during kharif. Agric. Sci. Digest., 35(3): 224-228.

Krishna, K. S. S. R. and George, P. J., 2017, Effect of levels of phosphrous and zinc on growth and yield of Kabuli chickpea (Cicer kabulium L.), J. Pharmacogn. 
and Phytochem., 6(4): 1013-1016.

Mahantesh, S.K., 2013, Response of chickpea (Cicer arietinum L.) to identified micronutrients constraints under vertisols of malaprabha command area in Karnataka. Msc (agri). Thesis, Univ. Agric. Sci., Dharwad , Karnataka (India).

Mukundgouda, K., Halepyati, A. S., Koppalkar, B. G., 2014, Response of pigeonpea (Cajanus cajan L. Millsp.) to application of micronutrients through soil and foliar spray of macronutrients on yield, economics and protein content. Karnataka J. Agric. Sci., 27(4): $460-463$.

Price, C. A., Clrak, H.E. and Funkhouser, 1972, Functions of micronutrients in plants. In: Micronutrients in Agriculture, Soil Science Society of American International, Madisan, Wisconsin, pp. 1731-1742.

Rathod, P.S., Dodamani, B.M. and Patil, D.H., 2016, Effect of micronutrients on growth and productivity of pigeonpea under rainfed conditions. Res. Environ. Life Sci., 9(6): 748-750.

Ramaprasad, D. P., Rao, C. P. and Srinivasulu, K., 2011, Effect zinc management on yield and nutrient uptake of Kabuli chickpea. The Andhra Agric. J., 58(3): 258-261.

Roy, P. D., Lakshman, K., Narwal, R. P., Malik, R. S., and Saha, S., 2017, Green gram (Vigna radiata L.) productivity and grain quality enrichment through zinc fertilization. Int. J. Curr. Microbiol. App. Sci., 6(6): 643-648.

Sharma, A., Nakul, H. T., Jelgeri, B. R. and Surwenshi, A., 2010, Effect of micronutrients on growth, yield and yield components in pigeonpea (Cajanus cajan (L.) Millsp.). Res. J. Agric. Sci., 1(2): 142- 144.

Shinde, P., Doddagoudar, S. R., and Vasudevan, S.N., 2017, Influence of seed of polymer coating with micronutrients and foliar spray on seed yield of chickpea (Cicer arietinum L.). Legume Res., 40(4): 704-709.

Srikanth Babu, P. N., Koppalkar, B. G., Nagalikar, V. P. and Pramod Katti, 2012, Yield and yield components and economics of pigeonpea cultivation as influenced by organic manures and graded levels of zinc sulphate. Karnataka J. Agric. Sci., 25(4): 527530.

\section{How to cite this article:}

Saakshi, R. Almad, Pandit S. Rathod, V. Rachappa, B. M. Dodamani and Ananda. N. 2020. Growth, Yield and Economics of Pigeonpea as Influenced by Biofortification of Zinc and Iron. Int.J.Curr.Microbiol.App.Sci. 9(02): 3088-3097. doi: https://doi.org/10.20546/ijcmas.2020.902.356 